\section{AL-AZHAR}

Assiut Dental Journal
The Official Publication of The

Faculty of Dental medicine.

Al-Azhar Assiut Uniuersity.

Egypt

AADJ, Vol. 2, No. 1, APRIL (2019) - PP. 21:29

ISSn 2682-2822

\title{
Efficacy of Regenerative Materials and Ultrasonic Ridge Splitting Technique with Simultaneous Implants Placement into Narrow Alveolar Ridge
}

\author{
Asem Mohamed Kamel ${ }^{* 1}$, Ahmad Kassem Mohammad ${ }^{1}$, Mohamad Fouad Edrees ${ }^{1}$
}

Codex : 03/1901

Aadj@azhar.edu.eg

\section{KEYWORDS}

Bone grafting , HA, ridge splitting, Tricalcium phosphate,

1. Department of Oral Medicine, Periodontology, Diagnosis and Oral Radiology, Faculty of Dentistry, Al-Azhar University, Assiut

* Corresponding author e-mail: asemali.dent.ast.b@azhar.edu.eg

\begin{abstract}
Aim: This study compares clinically and radiographically between efficacies of two different bone graft materials with amniotic membrane in narrow alveolar ridges subjected to ridge expansion by ultrasonic bone surgery to receive simultaneous implant placement. Subjects and Methods: Twenty-two systemically healthy patients with partial edentulous narrow anterior maxillary ridge classified randomly into the following equal groups: Group I patients with partial edentulous narrow ridge; treated by ridge splitting technique and simultaneous implant placement into their ridge; associated with deproteinized bovine bone (Bio-Oss ${ }^{\circledR}$ ) and amniotic membrane. Group II patients with partial edentulous narrow ridge; treated by ridge splitting technique and simultaneous implant placement into their ridge; associated with hydroxyapatite and $40 \%$ beta-tricalcium phosphate (easy-graft ${ }^{\mathrm{TM}}$ crystal) and amniotic membrane. Evaluation of implant success rate was done, and the clinical parameters were recorded for all implants. Implant stability quotient (ISQ) values was recorded. Efficacy of regenerative materials was observed by evaluation of marginal bone level and bone density. Results: Alveolar ridge width was increased in all groups. The mean value of alveolar ridge width in group I $3.64 \mathrm{~mm} \pm 0.3$ at baseline that increased to $6.90 \mathrm{~mm} \pm 0.6$. The mean value of Alveolar ridge width in group II was $4.17 \mathrm{~mm} \pm 0.7$ at baseline that increased to $6.65 \mathrm{~mm} \pm 0.4$. Group II showed the highest ISQ, bone density and the lowest marginal bone loss values after twelve months of implant placement. Conclusion: The use of piezo-electric surgery with bone grafting as sole tool for ridge splitting is promising technique.
\end{abstract}

\section{INTRODUCTION}

Consequent to tooth loss, resorption of alveolar bone occurs as a result of physiologic healing ${ }^{(1)}$. The estimated structural loss is about $60 \%$ of pre-extraction alveolar ridge width; this loss has a detrimental effect on potential treatment with a dental implant ${ }^{(2)}$. Various surgical widening techniques have been described, including lateral augmentation with or without guided bone regeneration (GBR) and horizontal distraction osteogenesis. Expansion of the existing residual ridge is 
another method and is referred as, bone spreading, ridge expansion, the osteotomy or ridge splitting technique ${ }^{(3)}$.

Ridge splitting technique creates a sagittal osteotomy of the edentulous ridge using instruments such as chisels between the two cortical plates to expand the ridge width and consequently allow for the placement of implants. This approach is used to expand the edentulous ridge for implant placement or insertion of an interpositional bone graft ${ }^{(4)}$.

The use of ultrasonic bone surgery represents an advantageous alternative technique to perform split-crest procedure over conventional surgery using disks and chisels. Ultrasonic device has the ability to cut mineralized hard tissues as bone in a very safe and precise way, with minor tissue damage ${ }^{(5,6)}$. Guided bone regeneration (GBR) is a well-documented procedure that designed to provide narrow alveolar ridge augmentation and correct development of deficient implant $\operatorname{sites}^{(7)}$. The rationale underlying the GBR protocol lies in the prevention of undesirable, non-osteogenic cells from growing into the bony defect by providing a mechanical barrier. There is strong evidence for the effectiveness and predictability of GBR in promoting vertical and lateral bone augmentation of ridge deficiencies ${ }^{(8)}$.

Wound healing in these cases is similar to the fracture repair of bone. The gap fills with a blood clot that organizes and is replaced with woven bone. If significant large critical bony gap occur or the facial plate separates at the base, bone graft materials such as particulate bone or cortical struts may be inserted within the osteotomy ${ }^{(9)}$. In circumstances where the wound is too large to generate a biomechanically stable central scaffold, bone formation is limited to the marginal stable zone with a central zone of disorganized loose connective tissue. Thus, combined use of bone grafts or bone replacement substitutes with barrier membranes are the best for bone regeneration of larger defects ${ }^{(10)}$.Simultaneous guided tissue regeneration (GTR) procedures, using bone grafts with barrier membranes, are usually necessary to correct peri-implant defects and/ or to augment surrounding tissues. This approach can also, achieve successful treatment outcomes of ridge expansion associated with implant placement with high predictability and a low risk of complications $^{(11)}$.

\section{SUBJECTS AND METHODS}

\section{Study setting and population:}

Twenty-two systemically healthy patients (12 females and 10 males, ranged in age from 2337 years with mean age of 29 years) with partial edentulous narrow anterior maxillary ridge were motivated to implant placement.

\section{Inclusion criteria:}

- Missing a single or multiple teeth in the anterior maxillary region after at least three months of socket healing.

- Crestal residual ridge width ranging from 3 to 5 $\mathrm{mm}$ at the crest and 6 to $8 \mathrm{~mm}$ at the basal part of the ridge.

\section{Exclusion criteria:}

- Conditions that complicate wound healing, for example, uncontrolled diabetes (defined as HBA1c level $>7 \%$ ) or smoking

- Perforated and/or lost labial bony plate.

- Obvious undercut on the labial cortical plate.

- Severe parafunctional habits; bruxism and clenching.

\section{Sample size calculation and power analysis:}

For the sample size calculation, the power analysis was performed using $\mathrm{G}$ Power system (G Power, Ver. 3.192 copy right 1992-2014) for a one-way fixed effect analysis of variance (ANOVA). The criterion for significance was 
set at $\alpha=0.05$ (type I error) and $\beta=0.20$ (type II error). The sample size is 12 cases per group. By calculating a dropout rate of $10 \%, 11$ cases per group resulting in a power of 0.9836804 .

\section{Surgical procedures:}

- A full thickness flap reflection of the labial and palatal mucoperiosteal flap was done.

- Using a piezosurgical device Piezotome $\mathrm{SOLO}^{\circledR}$ (Satelec Acteon, Bordeaux-Merignac, France), a crestal corticotomy cut was made in the alveolar ridge by CS 1 . Then, this crestal corticotomy cut widened by CS 2 to a depth of splitting reached to $8 \mathrm{~mm}$.

- On the mesial and distal ends of the corticotomy ( $2 \mathrm{~mm}$ away from adjacent teeth), vertical cuts were made on the buccal cortex by CS3 to a corresponding depth.

- Once the buccal-relief osteotomies were completed and checked for precise connection to the mesio-distal osteotomy the buccal bone plate then was distracted step by step with the CS 4 Tip (thickness, $1.8 \mathrm{~mm}$ ).

- CS 5 Tip (thickness, 2.75mm) and CS 6 Tip (thickness, $3.75 \mathrm{~mm}$ ) might be used to further distraction.

- The distracted and fully mucoperiosteal connected buccal plate was carefully checked visually and by blunt periodontal probes for perforations, fractures of the apical distraction baseline and accidental vertical fractures.

- Pilot drilling was performed with a 2.2-mmdiameter pilot drill (minimum 2 - $3 \mathrm{~mm}$ deeper than the depth of the osteotomy) for correct anatomical positioning of the planned dental implants.

- 2.8-mm-diameter spiral drill was easily inserted for preparing the depth of the site.
- Preparation of the implant site continued with the $3.5 \mathrm{~mm}$ diameter spiral drill.

- Standard implant is placed in the site, with the rough surface positioned at the level of the alveolar ridge crest. This allows the implant shoulder to be located at the gingival level.

- The Superline \& Narrow Ridge Dentium ${ }^{\circledR}$ implants (Dentium, Seoul, Korea) inserted until bone level.

- In group $1 \& 2$, the remaining gap filled with Bio-Oss ${ }^{\circledR}$ (Geistlich AG, Wolhusen, Switzerland) \& Easy-graft ${ }^{\mathrm{TM}}$ CRYSTAL (Degradable solution AG, Wagistrasse, Schlieren, Switzerland) respectively. Then grafted site covered by amniotic membrane. By using Osstell ${ }^{\mathrm{TM}}$, (Integration Diagnostics Ltd., Goteborgsvagen, Sweden) primary stability recorded. Implant stability quotient (ISQ) values taken immediately after implant placement were measured in triplicate and averaged to yield the mean baseline ISQ value for each implant. Additional Resonance frequency analysis (RFA) measurements were taken at the 6 months follow-up reentry for prosthetic procedures.

- After 6 months, submerged healing period, the patients were called back for the second stage surgery. Definitive abutments were tightened using $35 \mathrm{Ncm}$ torques. The final porcelain prostheses were cemented.

\section{Clinical photographs:}

In all groups, every procedure was documented by photographs at different observation periods of the study (fig 1,2).

\section{Periodontal Evaluation:}

Modified plaque index, Modified bleeding index ${ }^{(12)}$ and Probing depth (PD) were recorded for all implants at 6,9 and 12 months; 




Fig. (1) Showing clinical photographs of missing upper right central incisor in Group I patient who subjected to different steps including; splitting \&Widening of alveolar ridge and two vertical releasing bony incisions, Implant site preparation by surgical implant motor drill, Implant in its site, Bio-Oss ${ }^{\circledR}$ application to fill Peri-implant area and labial wall, Amniotic membrane application to cover area of surgery, Flap repositioning and interrupted sutures, Prosthetic abutment with impression coping and finally Porcelain crown in place.

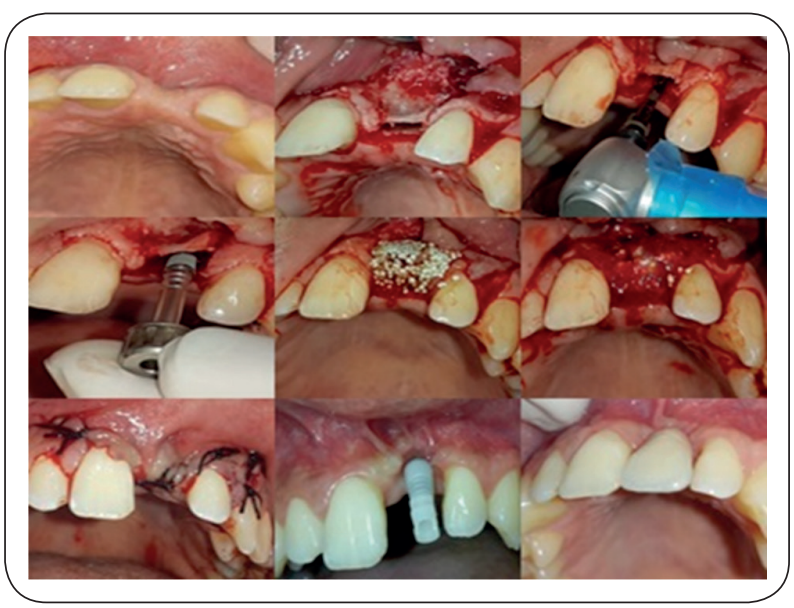

Fig. (2) Showing clinical photographs of missing upper left central incisor in Group II patient who subject to splitting of narrow ridge by CS1, Widening of alveolar ridge and two vertical releasing bony incisions, Implant site preparation by surgical implant motor drill, Implant insertion, Easy graft crystal ${ }^{\mathrm{TM}}$ application to fill Periimplant area and labial wall, Amniotic membrane application to cover area of surgery, Flap repositioning and suturing with interrupted non- resorbable stitches, Prosthetic abutment with impression coping and finally porcelain crown in place.

\section{Post-operative ridge width:}

It was measured with postoperative16-Slice Computed Tomogram Scanner.

2. Measuring of marginal bone loss: Marginal bone loss around the implant was evaluated using photon collection system of vistascan ${ }^{\circledR}$ (Durr Dental GmbH\& Co. BietigheimBissingen, Germany) that were taken on the day of the implant placement (baseline) and on the follow-up visits at 3, 6,9 and 12 months.

3. Measuring of bone density: Average density is determined using Bioquant ${ }^{\circledR}$ (Bioquant Image Analysis Corporation, Nashville, TN, USA).

4. Statistical analysis: The data were collected, tabulated and statistically analyzed by Statistical Package for Social Sciences (SPSS) version 20.

\section{RESULTS}

27 dental implants were placed in narrow anterior region of maxillary ridge immediately after the ridge split procedure. Implant diameter ranged from 3.1 to $3.6 \mathrm{~mm}$ while implant length ranged from 11 to $14 \mathrm{~mm}$. The period of observation (placement then loading) of the implants was 12 months. During the periods of the study; one out of twenty-seven implant showed mobility, radiolucency and periimplant inflammation (3.7\%). Three out of twenty seven implant exhibited partial membrane exposure at the 10-day post-operative check, and re-entry was performed to cover the implant. The post- operative healing was uneventful in all other 19 patients.

Changes in clinical parameters: in modified Plaque Index (mPI): Plaque accumulation around marginal area of implants increased by the end of observation period in all groups. Comparing two groups showed no statistical significant changes observed between each groups at 6,9 and 12 month. In modified Bleeding Index (MBI): degree of gingival bleeding around implants increased by the end of observation period in all groups. Probing 
depth increased gradually by the end of the study in all groups. The accretion of probing depth in all groups occurred but it still in acceptable range $(\leq 3 \mathrm{~mm})$. (Table 1).

Table (1) Illustrating means of modified Plaque Index, of modified bleeding Index and Probing depth in all groups during different intervals

\begin{tabular}{|c|c|c|c|c|}
\hline & Intervals & $\begin{array}{l}\text { Means } \\
\text { of } m \text { PI }\end{array}$ & $\begin{array}{l}\text { Means } \\
\text { of } \mathrm{mBI}\end{array}$ & $\begin{array}{c}\text { Probing } \\
\text { depth (mm) }\end{array}$ \\
\hline \multirow{3}{*}{$\begin{array}{l}\vec{Z} \\
\stackrel{0}{0} \\
\dot{0}\end{array}$} & 6 month & 0.340 & 0.159 & 2.02 \\
\hline & 9 month & 0.431 & 0.318 & 2.20 \\
\hline & 12 month & 0.522 & 0.477 & 2.29 \\
\hline \multirow{3}{*}{$\begin{array}{l}= \\
\stackrel{\Xi}{0} \\
\stackrel{0}{0}\end{array}$} & 6 month & 0.295 & 0.136 & 2.09 \\
\hline & 9 month & 0.340 & 0.295 & 2.20 \\
\hline & 12 month & 0.477 & 0.545 & 2.50 \\
\hline
\end{tabular}

Changes in Implant Stability Quotient (ISQ) and alveolar ridge width: ISQ increased at 6 month of observation interval in all groups. When comparing ISQ between groups, showed no statistical significant difference at baseline and 6 month interval of observation period. comparing pre-operative $\&$ post-operative alveolar ridge width between groups; it showed no statistical significant difference between all groups pre-operatively \& post-operatively. (Table 2)

Table (2) Illustrating means of Implant Stability Quotient (ISQ) and Pre- \& post-operative alveolar ridge width in all groups during two different intervals

\begin{tabular}{|c|c|c|c|}
\hline & Intervals & $\begin{array}{c}\text { Means of Implant } \\
\text { Stability Quotient } \\
\text { (ISQ) }\end{array}$ & $\begin{array}{c}\text { Means of Pre- \& } \\
\text { post-operative } \\
\text { alveolar ridge } \\
\text { width }\end{array}$ \\
\hline \multirow{2}{*}{ 官 } & baseline & 69.18 & 3.64 \\
\hline & 6 month & 76.45 & 6.90 \\
\hline \multirow{2}{*}{ 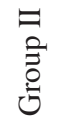 } & baseline & 69.00 & 4.17 \\
\hline & 6 month & 77.36 & 6.65 \\
\hline
\end{tabular}

Changes in Marginal bone level (MBL): When comparing G II VS. G I, it showed no statistical significant difference at 6 month of observation period, while it showed statistical significant difference during 3 and 9 month of observation periods of the study and high statistical significant difference at 12 month of observation periods. This diminution in marginal bone level in all groups occurred but it still in acceptable range $(\leq 1.5 \mathrm{~mm}$ in first year after implant placement). ((Table 3 )

Table (3): Illustrating mean $\pm S D$ values of marginal Bone loss scores among studied groups at each evaluation period, along with significance level using unpaired $t$-test.

\begin{tabular}{|c|c|c|c|c|c|c|c|c|}
\hline & \multicolumn{2}{|c|}{3 month } & \multicolumn{2}{|c|}{6 month } & \multicolumn{2}{|c|}{9 month } & \multicolumn{2}{|c|}{12 month } \\
\hline Group I & \multicolumn{2}{|c|}{$0.40 \pm 0.05$} & \multicolumn{2}{|c|}{$0.50 \pm 0.00$} & \multicolumn{2}{|c|}{$1.00 \pm 0.04$} & \multicolumn{2}{|c|}{$1.50 \pm 0.04$} \\
\hline $\begin{array}{l}\text { Group } \\
\text { II }\end{array}$ & \multicolumn{2}{|c|}{$0.30 \pm 0.05$} & \multicolumn{2}{|c|}{$0.40 \pm 0.05$} & \multicolumn{2}{|c|}{$0.90 \pm 0.04$} & \multicolumn{2}{|c|}{$1.10 \pm 0.04$} \\
\hline \multicolumn{9}{|c|}{ Unpaired t -Test } \\
\hline \multirow{2}{*}{$\begin{array}{c}\text { G I Vs. } \\
\text { G II }\end{array}$} & $\mathrm{t}$ & $\mathrm{p}$ & $\mathrm{t}$ & $\mathrm{p}$ & $\mathrm{t}$ & $\mathrm{p}$ & $\mathrm{t}$ & $\mathrm{p}$ \\
\hline & 2.7 & $0.01 *$ & 2.6 & 0.11 & 2.3 & $0.02 *$ & 3.5 & $0.00 * *$ \\
\hline
\end{tabular}

Changes in Bone Density Measurements (BD): Paired t-test showed gradual reduction in bone density readings during all of observation periods of the study in all groups. Unpaired-test used for comparing G II vs. G I, it showed no statistical significant difference at all intervals.

Table (4) Illustrating mean $\pm S D$ values of Bone Density scores among studied groups at each evaluation period, along with significance level unpaired t-test.

\begin{tabular}{|c|c|c|c|c|c|c|c|c|c|c|}
\hline & \multicolumn{2}{|c|}{ Baseline } & \multicolumn{2}{|c|}{3 month } & \multicolumn{2}{|c|}{6 month } & \multicolumn{2}{|c|}{9 month } & \multicolumn{2}{|c|}{12 month } \\
\hline & \multicolumn{2}{|c|}{$\begin{array}{c}188.55 \\
\pm 5.75\end{array}$} & \multicolumn{2}{|c|}{$\begin{array}{c}170.82 \\
\pm 7.17\end{array}$} & \multicolumn{2}{|c|}{$\begin{array}{c}166.91 \\
\pm 7.98\end{array}$} & \multicolumn{2}{|c|}{$\begin{array}{c}155.91 \\
\pm 8.78\end{array}$} & \multicolumn{2}{|c|}{$\begin{array}{c}152.91 \\
\pm 9.32\end{array}$} \\
\hline $\begin{array}{c}\text { Group } \\
\text { I }\end{array}$ & \multicolumn{2}{|c|}{$\begin{array}{c}190.91 \\
\pm 4.01\end{array}$} & \multicolumn{2}{|c|}{$\begin{array}{l}165.55 \\
\pm 4.97\end{array}$} & \multicolumn{2}{|c|}{$\begin{array}{l}163.45 \\
\pm 4.46\end{array}$} & \multicolumn{2}{|c|}{$\begin{array}{r}159.27 \\
\pm 4.65\end{array}$} & \multicolumn{2}{|c|}{$\begin{array}{r}159.09 \\
\pm 3.45\end{array}$} \\
\hline $\begin{array}{c}\text { Group } \\
\text { II }\end{array}$ & \multicolumn{2}{|c|}{$\begin{array}{c}188.55 \\
\pm 5.75\end{array}$} & \multicolumn{2}{|c|}{$\begin{array}{c}170.82 \\
\pm 7.17 \\
\end{array}$} & \multicolumn{2}{|c|}{$\begin{array}{c}166.91 \\
\pm 7.98 \\
\end{array}$} & \multicolumn{2}{|c|}{$\begin{array}{c}155.91 \\
\pm 8.78 \\
\end{array}$} & \multicolumn{2}{|c|}{$\begin{array}{r}152.91 \\
\pm 9.32 \\
\end{array}$} \\
\hline \multicolumn{11}{|c|}{ Unpaired t -Test } \\
\hline \multirow{2}{*}{$\begin{array}{c}\text { G I Vs. } \\
\text { G II }\end{array}$} & $\mathrm{t}$ & $\mathrm{p}$ & $\mathrm{t}$ & $\mathrm{p}$ & $\mathrm{T}$ & $\mathrm{p}$ & $\mathrm{t}$ & $\mathrm{p}$ & $\mathrm{t}$ & $\mathrm{p}$ \\
\hline & 1.11 & 0.27 & 2 & 0.58 & 1.2 & 0.22 & 1.1 & 0.27 & 2.06 & 0.05 \\
\hline
\end{tabular}




\section{DISCUSSION}

Resorption resulted in reduced ridge width, which may preclude placement of endosseous dental implants unless properly prepared. As mentioned by Esposito et al (2007) ${ }^{(13)}$, the bone width is crucial for osseointegration and even more important for an aesthetic outcome. In the literature there are some guidelines available which suggested a zone of $1.5-2 \mathrm{~mm}$ of bone around the implant.

In both groups of this study, grafted site covered by resorbable membrane. This in accordance to Duncan \& Westwood (1997) ${ }^{(14)}$ they recommended that to decrease the crestal bone resorption and to prevent any soft tissue ingress into the split crest, membrane should cover the area of surgery, Contrary to Mounir et al (2014) ${ }^{(15)}$ they mentioned that periosteum act as a biological natural membrane in decreasing the amount of bone loss without any added membrane.

Implant success rate in this investigation was 96.4\%. In the opposite side, kaneke et al (2013) (16) concluded that this procedure has clinical limitations and potential prognostic risks, as relatively large bone loss around implants and adjacent teeth was observed 2 years postoperatively, and these resorption rates as seen in our cases tended to increase as compared with those placed in the conventional manner.

In this study, the average initial implant stability quotient (ISQ) values at surgery were 69.18 and 69.00 respectively. The implant stability quotient (ISQ) values at the time of surgery can be viewed as a low number in comparison with values after 6 months 76.45 and 77.36. This is expected since the implants placed immediately after the ridge split procedure may have lower primary stability due to main bone contact originated from apical aspect of the osteotomy site. These investigations comparable with study of Kreissel et al (2013) ${ }^{(17)}$ they were assessed the implant stability in expanded ridges, reported that bony micro-architecture had no consequence on implant stability, initial bone density, presence of a cortical layer. They also reported that the application of the spreaders significantly increased implant stability quotient (ISQ) values over the study period. In contrast, Padmanadhan \& Gupta (2010) ${ }^{(18)}$ \& Shaik et al $(2016)^{(19)}$ they demonstrated that primary stability mean value was 59.60 ISQ and secondary stability was 61.50 ISQ which were smaller to the results of the present study; but their results obtained after 3 months only.

In the present study, there was no correlation between marginal bone loss (BML) \& implant stability quotient (ISQ); this in agreement with Fischer et al (2009) ${ }^{(20)}$ they found that no correlation between marginal bone loss and RFA during a 1-year period. In contrary, study of Tözüm et al (2008) (21) found that a negative correlation between marginal bone loss around mandibular implants and implant stability; as bone loss increased, the ISQ values decreased.

In this trial, both groups showed less marginal bone loss. it hypothesized that showed less marginal bone loss (MBL) at 12 months because these (Group I \& II) were protected with amniotic membrane in early period of study. Also Group III showed less marginal bone loss than Group II, because presence of PLGA \& $\beta$-TCP were resorbed \& replaced earlier than deproteinized bovine bone mineral at 12 months. This finding similar to that obtained in Han et al (2011) ${ }^{(22)}$ study.

Marginal bone loss (MBL) results of current study were corroborated with Stricker et al (2015) (23) they concluded that in ridge expansion model in miniature pigs, the buccal bone volume was significantly better preserved with GBR when compared to a mucosal (i.e., partial-thickness) access flap without GBR, provided that soft tissue healing occurred complication free. In contrary with Tang et al (2013) ${ }^{(24)}$ they stated that regarding the MBL, no differences between alveolar ridge splitting in combination with GBR compared to ridge splitting without GBR were reported. 
High values of initial bone density in current study corresponding to a clinical densitometric study Alberti et al (2010) ${ }^{(25)}$ showed that revealed higher bone density around implants inserted following piezo- surgical osteotomy than observed around implants inserted following rotatory protocols.

\section{CONCLUSIONS}

1. The use of piezo-electric surgery as sole tool for ridge splitting is promising technique.

2. Utilization of regenerative materials combined with ridge splitting technique has fewer benefits in aspects of implant stability, crestal/marginal bone and bone density. The differences in using between Bio-Oss ${ }^{\circledR}$ and Easy graft ${ }^{\mathrm{TM}}$ CRYSTAL in splitting technique is unnoticeable.

\section{REFERENCES}

1. Pietrokovski J, Massler M. Alveolar ridge resorption following tooth extraction. J Prosthet Dent 1967; 17:21-7.

2. Werbitt M, Goldberg P. The immediate implant: bone preservation and bone regeneration. Int J Periodontics Restorative Dent 1992; 12:206-17.

3. Shimoyama T, Kaneko T, Shimizu S, Kasai D, Tojo $\mathrm{T}$, Horie N. Ridge widening and immediate implant placement. Implant Dent 2001; 10: 108-12.

4. Misch C. Implant site development using ridge splitting techniques. Oral Maxillofacial Surg Clin N Am 2004; 16: 65-74.

5. Vercellotti T, De Paoli S, Nevins M. The piezoelectric bony window osteotomy and sinus membrane elevation: Introduction of a new technique for simplification of the sinus augmentation procedure. Int $\mathrm{J}$ Periodontics Restorative Dent. 2001; 21: 561-67.

6. Berengo M, Bacci C, Sartori M. Histomorphometric evaluation of bone grafts harvested by different methods. Minerva Stomatol. 2006; 55: 189-98.

7. Rocchietta I, Fontana F, Simion M. Clinical outcomes of vertical bone augmentation to enable dental implant placement: A systematic review. J Clin Periodontol. 2008; 35:203-15.
8. Langer B,Langer L, Sullivan R. Vertical ridge augmentation procedure using guided bone regeneration, demineralized freeze-dried bone allograft, and mini-screws: 4- to 13year observations on loaded implants. Int J Periodontics Restorative Dent. 2010; 30:227-35.

9. Engelke W, Diederichs C, Jacobs H, Deckwer I. Alveolar reconstruction with splitting osteotomy and microfixation of implants. Int J Oral Maxillofac Implants 1996; 12:310-8.

10. Dimova C, Evrosimovska B, Zlatanovska K, Zarkova J. Alveolar Augmentation Using Different Bone Substitutes. In Antoniac I. Handbook of Bioceramics and Biocomposites.1sted. Switzerland; Springer: 2015 p1-42.

11. Chen S, Wilson T, Hammerle C. Immediate or early placement of implants following tooth extraction: review of biologic basis, clinical procedures, and outcomes. Int J Oral Maxillofac Implants 2004; 19:12-25.

12. Mombelli A, Lang N. Clinical parameters for the evaluation of dental implants. Periodontol 2000 1994; 4:81-6.

13. Esposito M, Murray-Curtis L, Grusovin M, Coulthard P, Worthington $\mathrm{H}$. Interventions for replacing missing teeth: different types of dental implants. Cochrane

14. Duncan J, Westwood R. Ridge widening for the thin maxilla: a clinical report. Int J Oral Maxillofac Implants 1997; 12:224-7.

15. Mounir M,Beheiri G, El-Beialy W. Assessment of marginal bone loss using full thickness versus partial thickness flaps for alveolar ridge splitting and immediate implant placement in the anterior maxilla. Int J Oral Maxillofac Surg 2014; 43: 1373-80.

16. Kaneko T, Masuda I,Hino S, Horie N, Shimoyama T. Dental implants placed in thin maxilla expanded using a modified bone-splitting procedure: Case series. J Oral Maxillofac Surg Med Pathol 2013; 25: 250-54.

17. Kreissel P, Kölpin F, Graef F, Wichmann M, Karl M. Effect of rotating osteotomes on primary implant Stability-an in vitro investigation. J Oral Implantol 2013; 39:52-57.

18. Padmanabhan T, Gupta R. Comparison of crestal bone loss and Implant stability among the implants placed with conventional procedure and using osteotome technique: A clinical study. J Oral Implantol 2010; 26:475-84.

19. Shaik L, Meka S, Kattimani V, Chakravarthi S, Kolli N. The Effect of Ridge Expansion on Implant Stability in Narrow Partially Edentulous Ridges-A Preliminary Clinical Study. J Clin Diagn Res 2016; 10: ZC28. 
20. Fischer K, Ba“ckstro“m M, Sennerby L. Immediate and early loading of oxidized tapered implants in the partially edentulous maxilla. A one-year prospective clinical, radiographic and resonance frequency analysis study. Clin Implant Dent Relat Res 2009; 11: 69-80.

21. Tözüm T, Turkyilmaz I, Yamalik N, Karabulut E, Türkyilmaz A, Eratalay K. Analysis of the possibility of the relationship between various implant-related measures: an 18-month follow-up study. J Oral Rehabil 2008; 35:95-104.

22. Han J, Shin S, Herr Y, Kwon Y, Chung J. The effects of bone grafting material and a collagen membrane in the ridge splitting technique: an experimental study in dogs. Clin Oral Implant Res 2011; 22: 1391-8.
23. Stricker A, Fleiner J, Dard M, Voss P, Sauerbier S, Bosshardt D. Evaluation of a new experimental model to study bone healing after ridge expansion with simultaneous implant placement-a pilot study in minipigs. Clin Oral Implant Res 2014; 25:1265-72.

24. Tang Y, Yuan J, Song Y, Ma W, Chao X, Li D. Ridge expansion alone or in combination with guided bone regeneration to facilitate implant placement in narrow alveolar ridges: a retrospective study. Clin oral implants res 2015 ; 26:204-11.

25. Alberti L, Donnini F, Alberti C, Camerino M. Acomparative study of bone densitometry during osseointegration: piezoelectric surgery versus rotary protocols. Quintessence International 2010; 41: 639-44. 


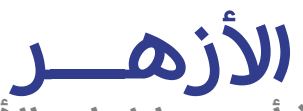 \\ مجلة أسيوط لطب الأسنان}

النشر الرسمي لكلية طب الأسنان

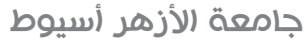

AADJ, Vol. 2, No. 1, April (2019) - PP. 29

الملخص العربي



تقارن هذه الدراسـة سـريريًا وإشـعاعيًا بين مؤثرات

اثنين من مواد العظام الصناعية الخُتلفة مع الغشاء الأمنيوسـي في الحافة السـنخية الضيقة التي يته توسعيها عن طريق جراحة العظام

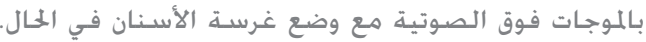

الموضوعات والأساليب:

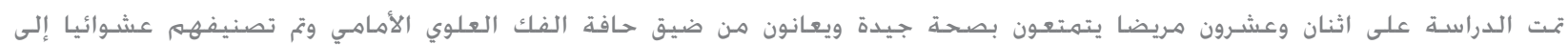



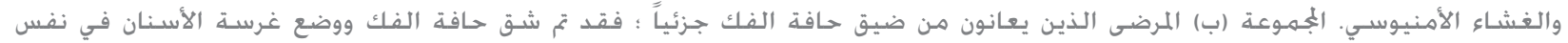

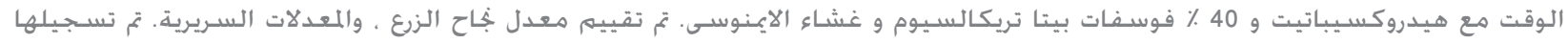

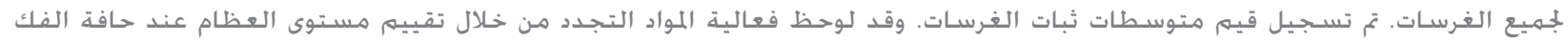

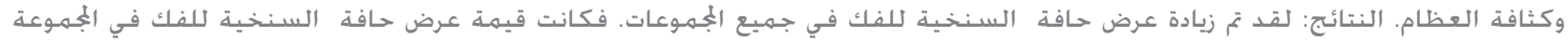

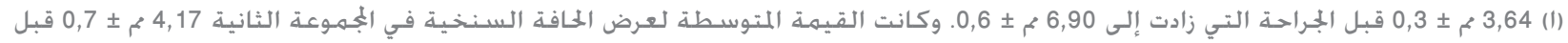



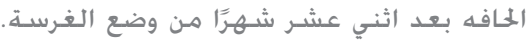

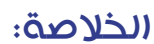

يعتبراستخـدام جـراحـة الموجات فوق الصوتيه كأداة لشـق حافه عظام الفك مع ترقيع العظام تقنية واعدة لزياده سـكك عظام الفك. 